R. Poppy Yaniawati (2013). E-Learning to Improve Higher Order Thinking Skills (HOTS) of Students. Journal of Education and Learning. Vol.7 (2) pp. 109-120.

\title{
E-Learning to Improve Higher Order Thinking Skills (HOTS) of Students
}

\author{
R. Poppy Yaniawati * \\ University of Pasundan
}

\begin{abstract}
The role of technology integration on modern learning is essential to optimize the acceleration process in Higher Order Thinking Skills (HOTS). This research describes how to implement e-learning to improve HOTS of students and students' attitude toward e-learning of mathematics, pre- learning students knowledge, duration of login in website, and correlation of variables with HOTS. The subject is 162 students in semester IV, from two different universities and are relatively different in their pre-learning knowledge. The instrument used in this research consisted of pre-learning knowledge HOTS test, students' attitude scale and technology (computer and internet) skills self test. Based on analysis of the data, it is concluded that students' HOTS who have studied through blended learning are much better than other learning (full e-learning and conventional approaches). Students' HOTS with conventional model is better than full e-learning. However, students' HOTS with full e-learning is worst than other learning (blended learning and conventional). The attitude of students towards e-learning in both learning approaches (blended learning and full e-learning) is positive. There is no significant difference in students' attitude to these two learning ways. There is a significant correlation between pre-learning knowledge and students' HOTS, but there is no significant correlation between students' HOTS and students' attitude toward e-learning of mathematics. There is a significant correlation between login duration and students attitude toward e-learning of mathematics. No significant correlation is found between login duration and students' HOTS.
\end{abstract}

Keywords: e-learning, blended learning, HOTS, students' attitude

${ }^{*}$ R. Poppy Yaniawati, University of Pasundan.

E-mail:p.yaniawati@gmail.ac.id ; opyaniawati@yahoo.com 


\section{Introduction}

Contemporary learning demands the learners to involve more actively to develop and dig their knowledge. The activities of learners is the core of learning process in the future, thus teacher's position in contemporary learning is as facilitator rather than as instructor. The tendency of position change of learners and teacher's role cause a change in the paradigm of learning, that prepares the learners to become a person who can study independently.

NCTM (2000) states that the learners have to study mathematics with understanding, it means learners have to develop their new knowledge actively from their own experience and previous knowledge. To achieve those things, it is formulated in 5 general aims of mathematics learning, i.e: first, learn to communicate (mathematical communication) second, learn to reasons (mathematical reasoning), third, learn to solve the problem (mathematical problem solving), forth, learn to connect an idea (mathematical connections) and fifth, forming the positive attitude towards mathematics (positive attitudes toward mathematics). These skills are normally called as Higher Order Thinking Skills (HOTS).

In this global era, to develop these skills an acceleration is required in mathematics learning process, because innovation about information occurs often very fast. By this acceleration, learners might have wider future horizon. In the acceleration context, technology is very important. Therefore, it is necessary to have Integrated Technology for Learning. UNESCO (Chaeruman, 2004) said that Integrated Technology of Telecommunication and Information for Learning has 3 goals: 1) To build "knowledge based society habits"; 2) To develop skills that use Technology (ICT Literacy); and 3) To enhance the effectivity and efficiency of learning process.

E-learning system is a kind of learning implementation that use of technology with web basis. Many educators define various definition of e-learning, as its explained by Cute (1999), "e-learning is instructional content or learning experiences delivered or enabled by electronic technology". Thompson (2000) says the advantage of e-learning which can give flexibility interactivity, speed and visualization through every advantage of each technology. According to Linde (2004), e-learning is a formal or informal ways of learning use electronic media such as internet, intranet, CD Room, Video tape, DVD, $\mathrm{TV}$, hand phone, PDA, etc.

UNESCO (Chaeruman, 2004) classifies utilization step of information telecommunication technology for learning into 4 steps as follows: 1) Emerging step, realize how important of information technology for learning but no effort to apply yet; 2) Applying step, one step ahead where the information technology has become an object to study (subject of study); 3) Integrating step, information technology has been integrated to curriculum (learning); 4) Transforming step, the most ideal step where information technology has become a catalyst for education change or evolution.

In the developing countries such as Indonesia, Information Technology in practice is still becoming an object or learning subject. The application of information technology is still in emerging and applying step forward to integrating step. But in some countries information technology has been used in learning process i.e. though e-learning. The benefit of this technology is used to solve the learning technical problem and also to answer the substance of learning problem.

E-learning can also be use to cover the lack of learning system. One of learning system which effective and efficient to use this technology is the distance learning system. Some of high educational institutions held an e-learning activity as a suplement for learning material provided as regularly in class room (Wildavsky, 2001). But some other High Educational Institutions held e-learning as an alternative for the students who are not able to attend face to face class for some reasons. In this case, e-learning has a function as an option for students. In spite of having advantages, e-learning has also weakness such as habitual of study of learner has to be supported. Therefore, a research is conducted to study about e-learning on students in tertiary education.

Aims of research are as follows:

\section{Aims of Research}

1. To analyze the difference of HOTS of Teacher College Students who studied full e-learning, blended learning, and conventional learning.

2. To analyze the difference of attitude of pre-service students to mathematics e-learning who studied with full e-learning and blended learning.

3. To analyze the correlation of pre-learning knowledge, login duration, HOTS, and attitude of students of teacher college to mathematics e-learning. 


\section{Methodology}

This experimental study implements 3 different treatments to different groups. The first group is called experiment- 1 who had been given full e-learning treatment $\left(\mathrm{X}_{1}\right)$, second group is called experiment-2, who had been given blended learning treatment $\left(\mathrm{X}_{2}\right)$, and the third group without obtaining treatment and conventional method and is called control group $\left(\mathrm{X}_{3}\right)$.

Description:

$$
\begin{array}{llll}
\text { R: } & \mathrm{O}_{1} & \mathrm{X}_{1} & \mathrm{O}_{2} \\
\text { R: } & \mathrm{O}_{1} & \mathrm{X}_{2} & \mathrm{O}_{2} \\
\text { R : } & \mathrm{O}_{1} & & \mathrm{O}_{2}
\end{array}
$$

$\mathrm{R}$ : Random system

$\mathrm{O}_{1}$ : Pre-learning knowledge test

$\mathrm{O}_{2}$ : Test HOTS

$\mathrm{X}_{1}$ : Treatment with full e-learning

$\mathrm{X}_{2}$ : Treatment with blended learning

\begin{tabular}{|c|c|c|c|c|c|c|}
\hline \multirow[b]{2}{*}{ University } & \multirow[b]{2}{*}{$\begin{array}{c}\text { Pre-learning } \\
\text { knowledge }\end{array}$} & \multicolumn{3}{|c|}{ HOTS } & \multicolumn{2}{|c|}{ Attitude } \\
\hline & & $\begin{array}{c}\text { Exp-1 } \\
\left(X_{1}\right)\end{array}$ & $\begin{array}{c}\text { Exp-2 } \\
\left(X_{2}\right)\end{array}$ & $\begin{array}{c}\text { Control } \\
\left(X_{3}\right)\end{array}$ & $\begin{array}{c}\text { Exp-1 } \\
\left(\mathrm{X}_{1}\right)\end{array}$ & $\begin{array}{c}\text { Exp-2 } \\
\left(\mathrm{X}_{2}\right)\end{array}$ \\
\hline \multirow{3}{*}{ A } & Superior & HSA-1 & HSA-2 & HSA-C & ASA-1 & ASA-2 \\
\hline & Low & HLA-1 & HLA-2 & HLA-C & ALA-1 & ALA-2 \\
\hline & Total & HA-1 & HA-2 & HA-C & AA-1 & AA-2 \\
\hline \multirow{3}{*}{ B } & Superior & HSB-1 & HSB-2 & HSB-C & ASB-1 & ASB-2 \\
\hline & Low & HLB-1 & HLB-2 & HLB-C & ALB-1 & ALB-2 \\
\hline & Total & HB-1 & HB-2 & HB-C & AB-1 & AB-2 \\
\hline $\begin{array}{c}\text { Combination A } \\
\text { and B }\end{array}$ & Total & H-1 & $\mathrm{H}-2$ & $\mathrm{H}-\mathrm{C}$ & A-1 & A-2 \\
\hline
\end{tabular}

Research design schematically is presented as below :

Table 1. Research Design Scheme

Description:

-1: experiment -1 group

-2 : experiment -2 group

$-\mathrm{C}$ : control group

A: University A

B: University B

$\mathrm{S}$ : superior students

$\mathrm{L}$ :low students

H: HOTS

A :students’ attitude

This research is involved two universities A and B. According to people opinion in general University A is much better than University B, This opinion is supported by data of students Mathematic grade who enter both these Universities. University A most of their candidat student averagely have got 8.42 of mathematics from final test result of senior high school. While University B have got averagely 7.15. Other difference between University A and B is from Accreditation which has been evaluated by "Badan Akreditasi Nasional Perguruan Tinggi“ (College National Acreditation Board) According its, Univerisity A has A level of acreditation, while University B has B level. The sample technique used is purposive sampling to represent level of college and academic year of students. Furthermore, grouping of experiment-1, experiment-2, and control was taken by random sampling. Number of participation in this study was 162 students, which consisted of 90 students from university A and 72 students from university B. table 2.

Design of learning process of each experiment group and control can be seen on following 
Table 2. Design of Learning Process

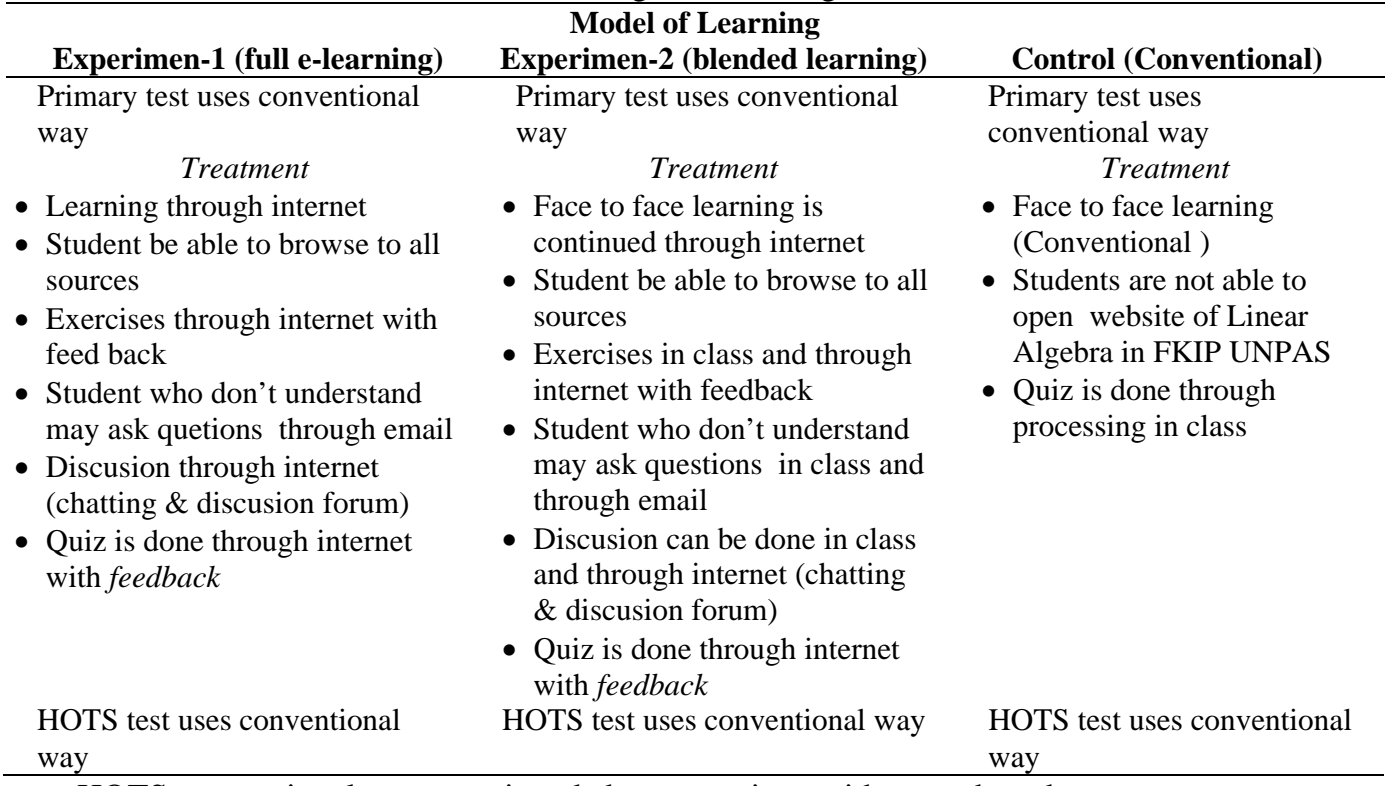

Notes : HOTS conventional tests mentioned above are given with paper based test

\section{Results and Discussions}

The result of descriptive statistic data for both university A and B can be seen on table 3 .

Table 3. Descriptive statistic of pre-learning knowledge and HOTS based on level of college

\begin{tabular}{|c|c|c|c|c|c|c|}
\hline University & Ability & Learning Model & Minimum & Maximum & Mean & SD \\
\hline \multirow{6}{*}{ A } & \multirow{3}{*}{$\begin{array}{l}\text { Pre-learning } \\
\text { knowledge }\end{array}$} & Full e-learning & 45 & 80 & 64.30 & 7.73 \\
\hline & & Blended learning & 45 & 90 & 65.17 & 10.9 \\
\hline & & Conventional & 45 & 85 & 65.93 & 9.84 \\
\hline & \multirow{3}{*}{ HOTS } & Full e-learning & 30 & 70 & 53.17 & 9.14 \\
\hline & & Blended learning & 38 & 75 & 60.63 & 9.59 \\
\hline & & Conventional & 35 & 75 & 57.23 & 12.33 \\
\hline \multirow{6}{*}{ B } & \multirow{3}{*}{$\begin{array}{l}\text { Pre- learning } \\
\text { knowledge }\end{array}$} & Full e-learning & 40 & 75 & 56.21 & 8.85 \\
\hline & & Blended learning & 40 & 75 & 55.58 & 8.58 \\
\hline & & Conventional & 35 & 75 & 56.75 & 9.96 \\
\hline & \multirow{3}{*}{ HOTS } & Full e-learning & 25 & 65 & 46.50 & 8.86 \\
\hline & & Blended learning & 35 & 70 & 50.54 & 9.00 \\
\hline & & Conventional & 25 & 68 & 48.17 & 11.36 \\
\hline \multirow{6}{*}{$\begin{array}{l}\text { Combination } \\
\mathrm{A} \text { and B }\end{array}$} & \multirow{3}{*}{$\begin{array}{l}\text { Pre-learning } \\
\text { knowledge }\end{array}$} & Full e-learning & 40 & 80 & 60.70 & 9.12 \\
\hline & & Blended learning & 40 & 90 & 60.91 & 10.96 \\
\hline & & Conventional & 35 & 85 & 61.85 & 10.83 \\
\hline & \multirow{3}{*}{ HOTS } & Full e-learning & 25 & 70 & 50.20 & 9.54 \\
\hline & & Blended learning & 35 & 75 & 56.15 & 10.54 \\
\hline & & Conventional & 25 & 75 & 53.20 & 12.64 \\
\hline
\end{tabular}

Based on the results received from the three learning groups in all levels of the two universities, HOTS of students has not achieved the criteria as it was expected, which is the achievement of study effectiveness, both individually or group .

\section{Students HOTS}

HOTS is measured by test, consisted of mathematical conection, mathematical comunication, reasoning, and problem solving. The grade written above on Table 3 is commpilation result. The measurement used statistical Cronbach Alpha, with cooficient 0.77. Score average data of student's HOT from both test average results can be seen in table 4 . 
Table 4. Score average student's HOT data

\begin{tabular}{|c|c|c|c|c|c|}
\hline $\begin{array}{l}\text { Level of } \\
\text { college }\end{array}$ & $\begin{array}{c}\text { Pre-learning } \\
\text { knowledge }\end{array}$ & $\begin{array}{c}\text { Full e-learning } \\
\left(\mathrm{X}_{1}\right) \\
\text { Mean (SD) }\end{array}$ & $\begin{array}{c}\text { HOTS } \\
\text { Blended } \\
\text { learning }\left(\mathrm{X}_{2}\right) \\
\text { Mean (SD) }\end{array}$ & $\begin{array}{c}\text { Conventional } \\
\left(\mathrm{X}_{3}\right) \\
\text { Mean (SD) }\end{array}$ & Mean \\
\hline \multirow{3}{*}{ A } & Superior & $59.00(5.57)$ & $68.13(4.96)$ & $65.00(8.02)$ & 64.04 \\
\hline & Low & $46.50(7.80)$ & 53.13 (6.73) & $47.08(9.20)$ & 48.90 \\
\hline & Total & 53.17 (9.14) & 60.63 (9.59) & 57.23 (12.33) & 57.01 \\
\hline \multirow{3}{*}{ B } & Superior & $52.80(7.12)$ & $59.30(5.31)$ & $56.73(6.51)$ & 56.28 \\
\hline & Low & 42.00 (7.17) & $44.29(4.75)$ & 40.92 (9.38) & 42.40 \\
\hline & Total & 46.50 (8.86) & 50.54 (8.99) & 48.17 (11.35) & 48.40 \\
\hline \multirow{3}{*}{$\begin{array}{c}\text { Combination } \\
\mathrm{A} \text { and } \mathrm{B}\end{array}$} & Superior & $56.62(6.81)$ & 64.60 (6.67) & $61.75(8.41)$ & 60.99 \\
\hline & Low & $44.25(7.70)$ & $48.86(7.30)$ & $44.00(9.63)$ & 45.70 \\
\hline & Total & $50.20(9.54)$ & 56.15 (10.54) & $53.20(12.65)$ & 53.18 \\
\hline
\end{tabular}

Note: ideal score is 100

In table 4. HOTS of students of the blended learning group was better compared to the other group. The blended learning group had wider concept in completing analytical matters than to the other group. Based on this fact. e-learning could widen the student concept and cultivated the creative way of thinking. This is in line with Soekartawi's opinion (2003) that learning through the internet might be able to increase science and wider concept.

The phenomenon blended learning was better compared to the other model. whereas full elearning was not better compared the other model. It showed that e-learning was not able to replace the conventional studying model in the class. but reinforced the conventional model through content enrichment and education technology development (Cisco in Kamarga, 2002).

The average score student's HOT data. based on learning model. pre-learning knowledge of students and college are presented on figure 1.

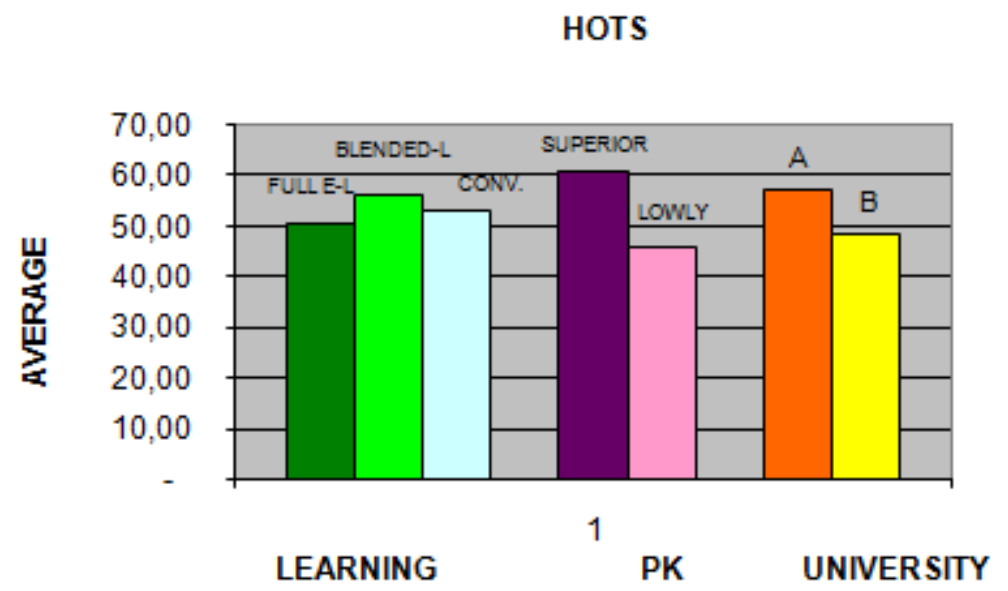

Figure 1. Average score students' HOT based on learning model pre-learning knowledge and level of college

Correspondence of pre-learning knowledge and learning model. and level of college and learning model are shown on the diagram below. (figure 2)

Mean of Marginal Estimation of HOTS 


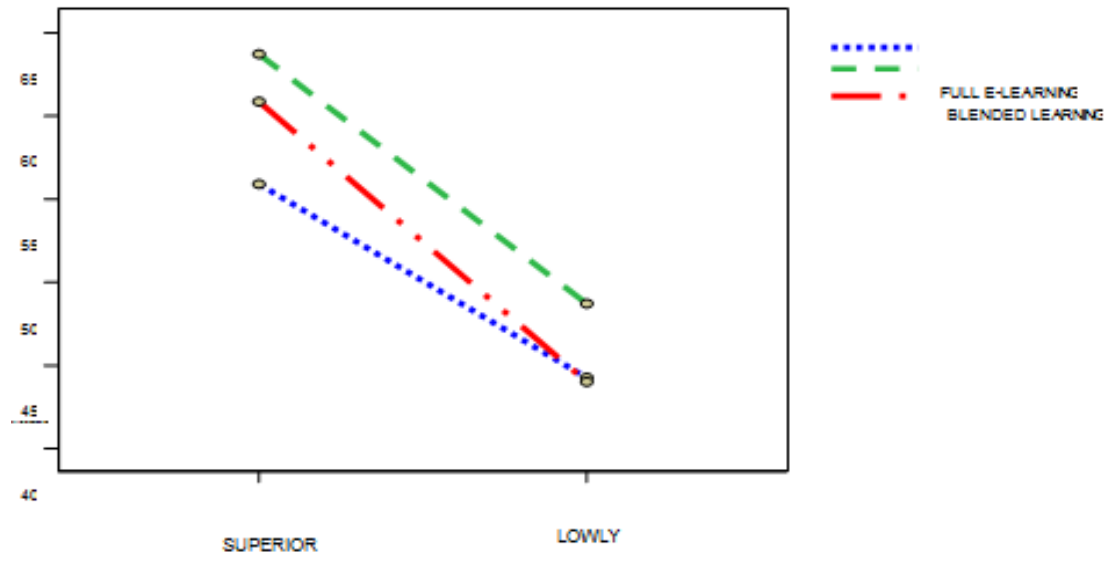

Figure 2. Correspondence between pre-learning knowledge \& learning model on combination of two colleges

The result shows that an interaction was not found between pre-learning knowledge and the learning model. In other words, there was not an influence of pre-learning knowledge on the three learning models in HOTS. This fact showed that the e-learning model could be accepted by all levels of students, although HOTS that was reached by the student was different for the certain learning model. In this case the possibility of the attitude factor can be took part in influencing these results. According to Triandis (1971). the attitude could influence the individual response to all the situations and the object that were connected to each other.

\section{Students' Attitude toward E-Learning}

The e-learning students attitude is measured by 40 items with Likert model use scale of five. The positive criteria are: 5 is equal to Strongly Agree; 4: Agree; 3: Netral; 2: Dissagree; 1 : Strongly Dissagree. The negative criteria are in reverse. Attitude scale is consissted of two components of Students attitude : 1) e- learning of Mathematic . 2) Tests of HOT . Result of attitude realibity test used statistical Cronbach Alpha. with cooficient 0.87. Students attitude to e-learning was obtained by 40 statements and average score of students attitude that achieved from sample of subject were classified based on learning model. level of college and pre-learning knowledge as shown in table 5 below.

Table 5. Students’ Attitude Average Score Data

\begin{tabular}{ccccc}
\hline \multirow{2}{*}{ University } & Pre-Knowledge & $\begin{array}{c}\text { Students' Attitude } \\
\text { Full e-learning }\left(\mathbf{X}_{\mathbf{1}}\right)\end{array}$ & $\begin{array}{c}\text { Blended learning } \\
\text { Mean (SD) }\end{array}$ & Mean (SD) \\
& Superior & $138.6(13.0)$ & $135.9(11.3)$ & Mean \\
\hline \multirow{2}{*}{ A } & Lowly & $129.5(13.4)$ & $136.9(7.9)$ & 137.3 \\
& Total & $134.3(13.7)$ & $136.1(8.7)$ & 135.2 \\
& Superior & $147.6(10.6)$ & $137.9(17.3)$ & 142.8 \\
B & Lowly & $135.1(9.6)$ & $130.3(10.8)$ & 132.7 \\
& Total & $140.3(11.6)$ & $132.4(15.2)$ & 136.4 \\
Combination of & Superior & $142.0(12.8)$ & $136.8(13.8)$ & 139.4 \\
A and B & Lowly & $132.3(11.8)$ & $133.9(9.8)$ & 133.1 \\
& Total & $137.0(13.1)$ & $134.7(12.3)$ & 135.9 \\
\hline
\end{tabular}

Note: ideal score is 200 and netral score is 120

The students' attitude towards e-learning in the two levels of two Universities were positive. On table 5, can be seen that average of attitude grade is more than 120 as a result of netral attitude on instrument scale. Generally the students felt happy when they opened the website. especially the animation available in the learning material. made them got a better understandingto the problem of mathematics that was taught. The students believe that e-learning has increased their concept and trained them to study independently. According to Mueller (1986). the attitude was a psychological conception and was hypo-thetical. Someone who had positive feeling towards a psychological object was hoped to increase his or her motivation. in this case the motivation of study. and it has the influential opportunity towards his study results as well. 


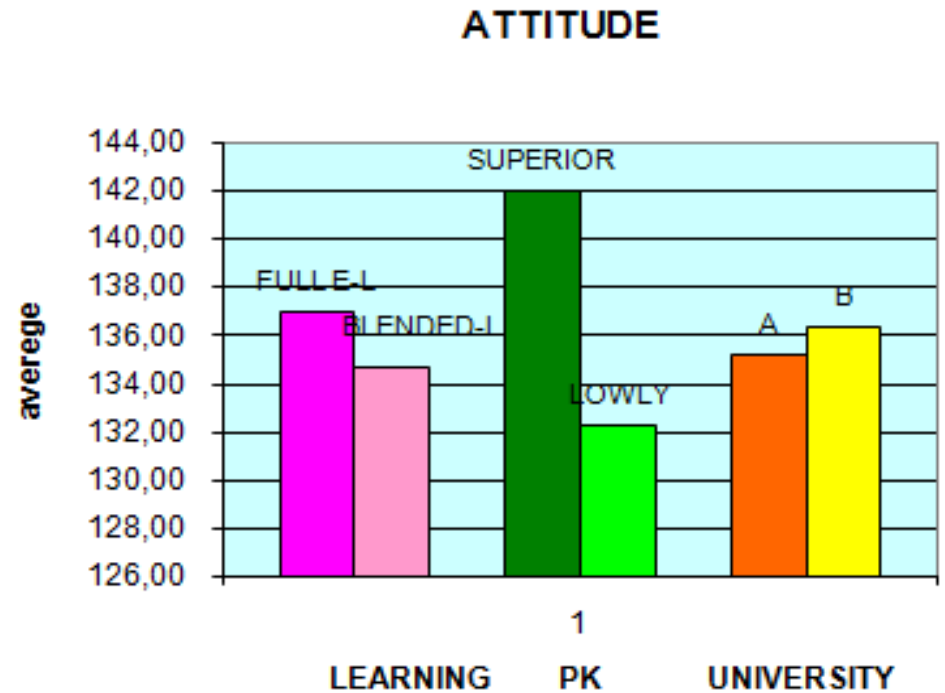

Figure 3. Score average of students attitude based on learning model. level of college and pre-learning knowledge.

Correspondence between pre-learning knowledge and learning model to student's attitude is presented below.

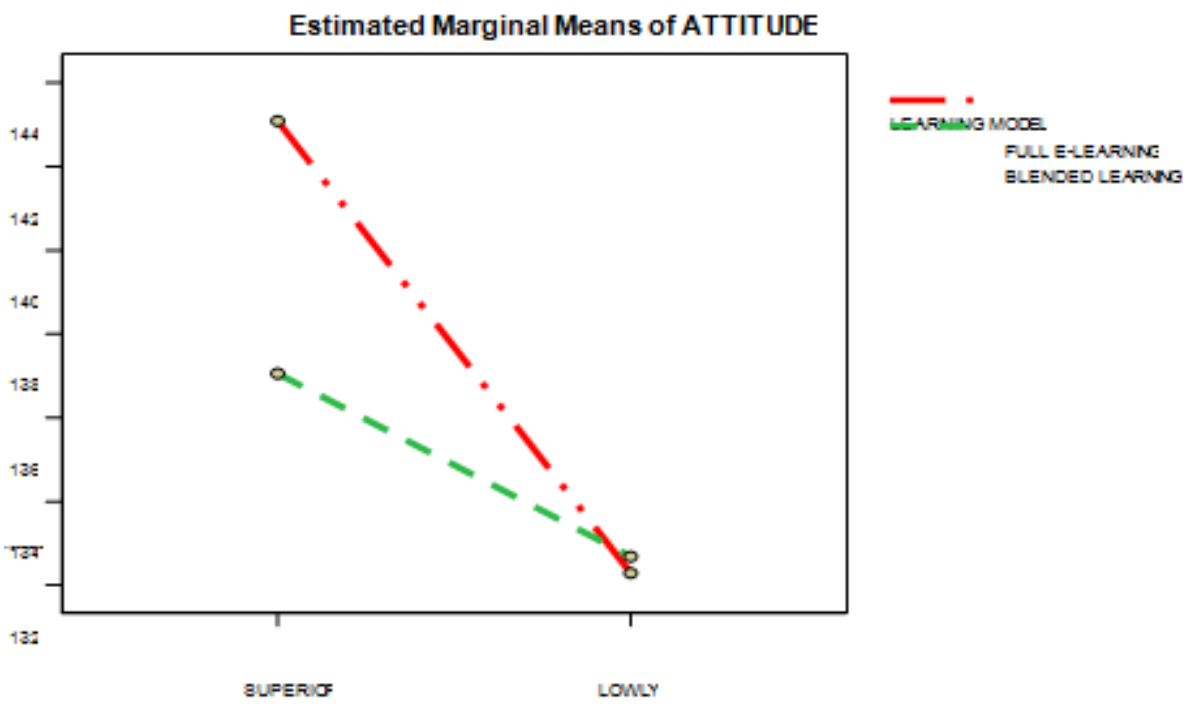

Figure 4. Correspondence between pre-learning knowledge and learning model at 2 universites combinated.

The result showed that there was not an interaction between pre-learning knowledge and the learning model. In other words there was no influence of pre-learning knowledge on the three learning in the attitude. This fact showed that the e-learning model is able to influence the attitude in all levels of the students. Attitude was the representation of the studying culture that could be developed in accordance to our expectation.

Based on the results obtained from the three learning groups of all levels of the two colleges observed. The students' mathematical power was in the category was "not sufficient". In a sense, it did not yet achieve the expected criteria, that is the achievement of the effectiveness in studying both 
individually as well as in groups. Most students still have difficulties in solving problems that consisted all aspects of the mathematical power. The students' mathematical power in the "good" category was the ability of the mathematical connection, whereas the "poor" is the students' reasoning ability (the deduction) in proving a statement or theorem.

The "poor" impact of the reasoning indicator resulted in the less developed student's way of thinking, shown by solving problems following the example the lecturer provided (routine). This fact is from the old culture that still happens in learning practice of student, does not evoke creativity.

In the blended learning group, in solving the problems that requires analysis, students relatively have wider concepts compared to students in the other group. Different than the other groups (full e-learning and conventional), the majority of student did not answer completely (emptied) the types of this analysis. Based on these facts, it could be seen that blended learning could widen the student's concept and cultivated a creative way of thinking.

The ability of superior students of the mathematical connections, problem solving and mathematical communication, is more capable than the ability of reasoning (deduction). However, for students asor, these skills are still lacking. Here is the work of students to solved the case 3 on the HOTS test by students of the full e-learning, blended learning and conventional. There is little difference in the way they pour the ideas of each group.

The case 3:

Review the vector $\cos (x+\alpha)$ and the vector $\sin x$ in the interval $[-\pi, \pi]$. Show that for the values $\alpha$ that are odd multiples $\pi / 2$ of the both vectors is dependent of linear. Give a geometric interpretation. (value 15)

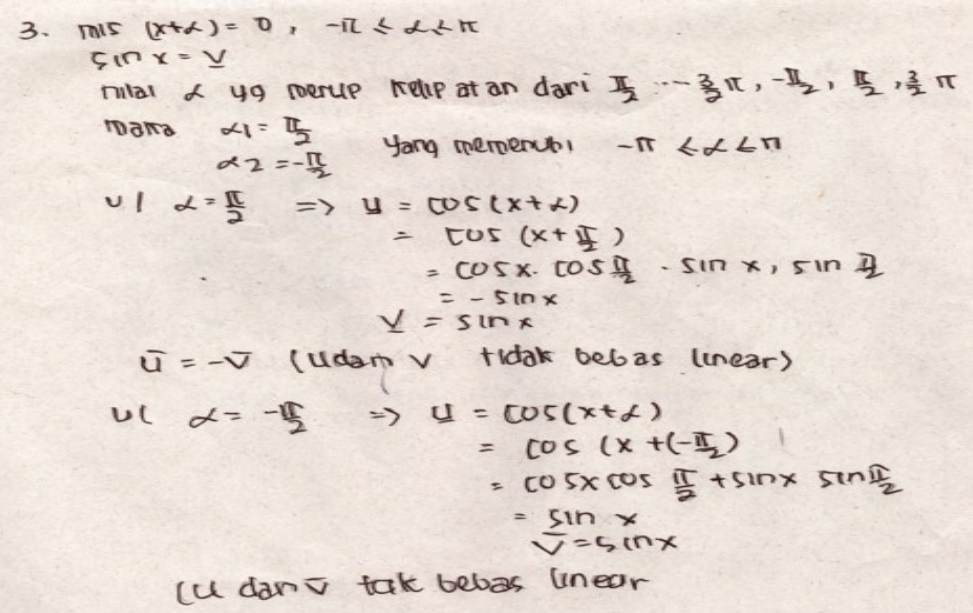

Figure 5. The work of a student from the conventional learning

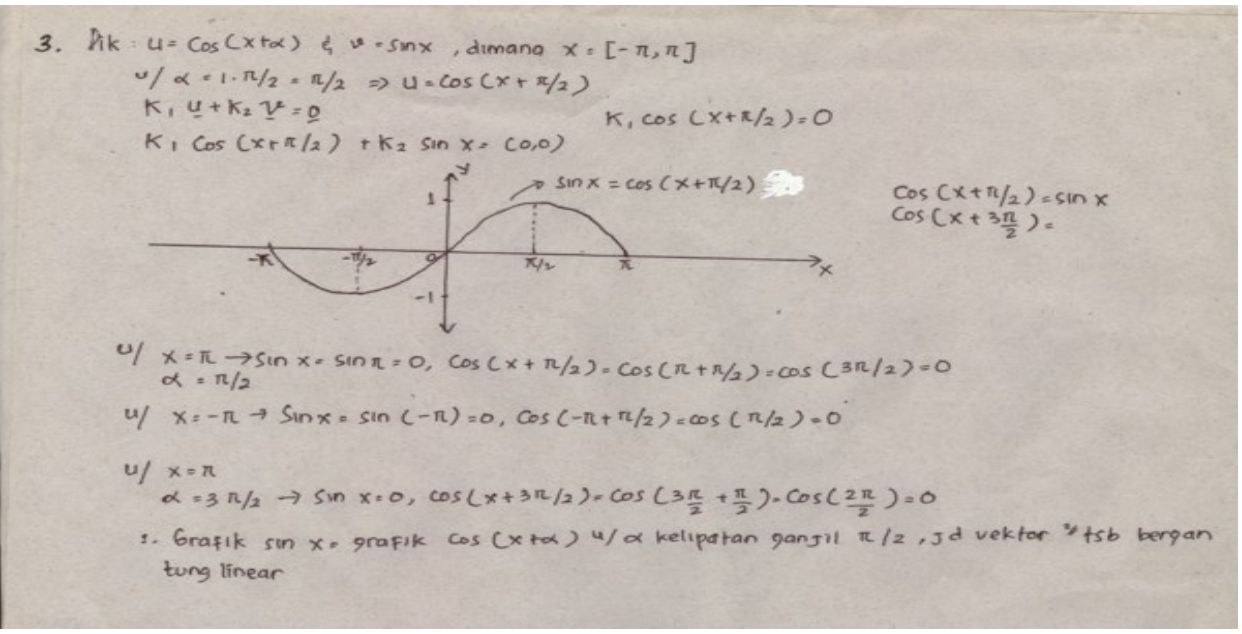

Figure 6. The work of a student from the blended learning 


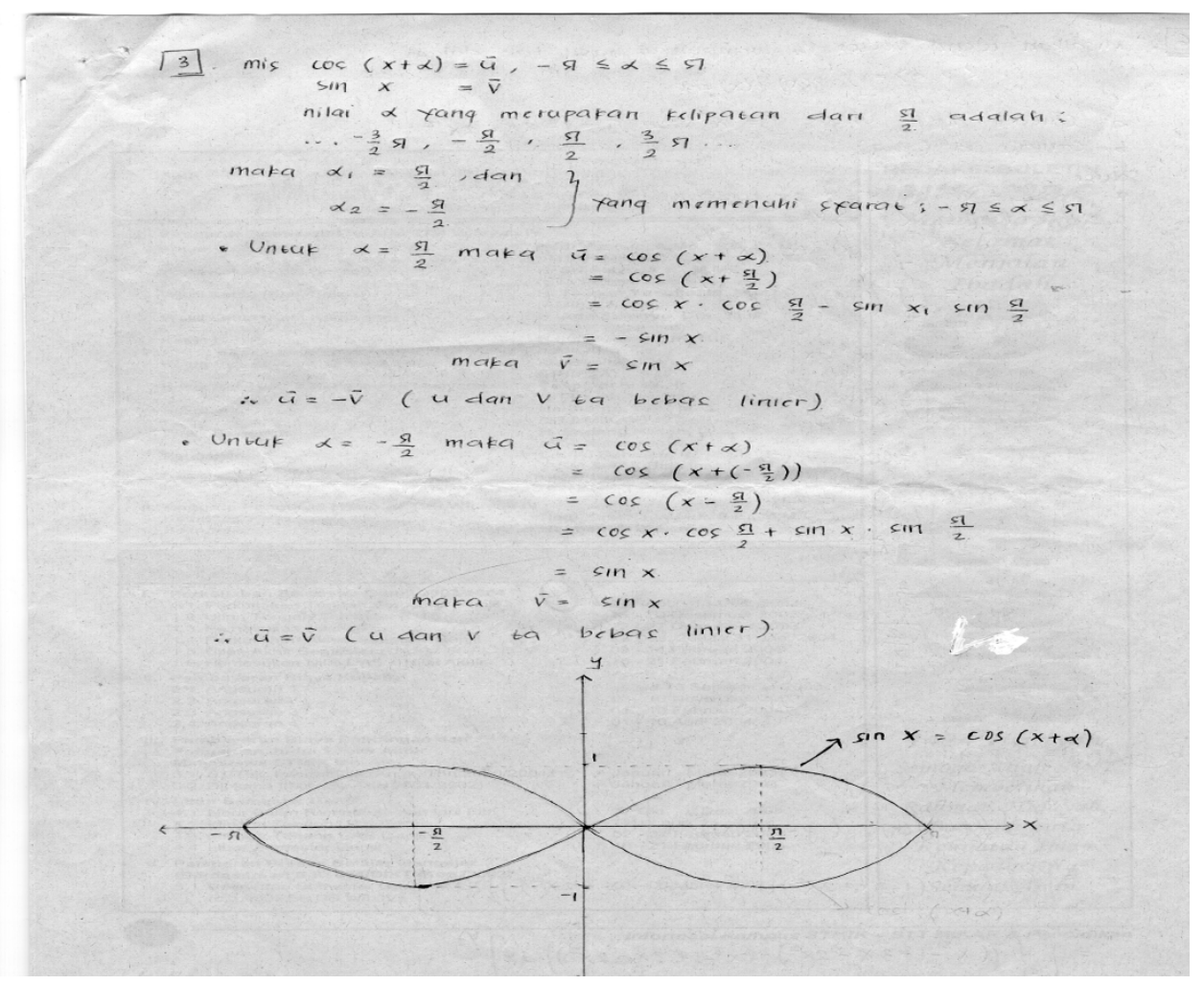

Figure 7. The work of a student from the full e-learning

Based on Figure 5, a student in the conventional group, how to pour his ideas using a standard trigonometric rules (to be routine), so that there is an error in the proceedings and without presenting the image as an illustration. In Figure 6, a student group of blended learning, how to pour the idea of using the linear independence rules or theorems that are not routine, and it presents a picture correctly as the illustrations, although there is still a shortage. However, in Figure 7, a student of the full e-learning, how to pour the ideas already present image as an illustration, while still using standard trigonometric rules that have been known since the beginning. Based on the students work can be seen that the full elearning and blended learning horizons wider than the conventional group. They've tried to visualize into the picture what they understand. So the understanding students of blended learning is better than the full e-learning, but the conventional is still routine.

Model of blended learning placed the function of e-learning as the supplement ( additional), that means the student required the studying options. whether they will utilize the material of e-learning or not (Siahaan, 2003). Thus, in the model of full e-learning the student studied fully through the internet, in this case the function of e-learning as the complement (the replacement) (Siahaan. 2003). Therefore, the student automatically had to learn independently. In this model, students' independence and responsibility were really needed. This is in accordance with the Wedemeyer opinion (Simonson. 1999) that regarded the independence of the student as an important matter in distance education. While based on the observation, students' self regulated learning was still not fully formed in this research. Soekartawi (2004) also states that in e-learning, the students was still inactive, so they should warned via letter or e-mail with a copy to the supervisor.

The utilization of technology (e-learning) identified was still not optimal yet. However, several active students used the forum for discussions and asked the lecturer through the email. The student's response could interpret as the early step (that was good), but not sufficient for the achievement of optimal results. The interaction that has to be maintained between the student and the lecturer through the media feedback contained in the website, was predicted that the students were more motivated to retry, especially during resolving quiz.

There are linkages between the prior knowledge and the power of mathematical knowledge of students. This shows that the students' prior knowledge affected the mathematical power. Apart from this, in student attitudes toward e-learning, login duration factors to the website could also influenced the mathematical power. The above results showed that the duration of the login has affected to the 
student attitudes toward e-learning. Students who browsed more often, evidently had more positive attitude towards e-learning.

The mastery of prior learning knowledge can produce a good mathematical power as well. But, the good attitudes toward e-learning was not suffice to be the prerequisite for obtaining good results in mathematical power. This showed that attitude was a "necessary condition" but not a "sufficient condition" to achieve better learning outcomes (in this case is the power of mathematics). Nevertheless, the attitudes could be the precondition of learning behavior, students with better study habits. that furthermore could produce a better mathematical power as well.

\section{Conclusions and Implications}

Based on the result of the research, the following conclusions that :

1. There was significant difference of student's HOTS between student of teacher college who were study with full e-learning and conventional. Though blended learning with conventional learning was not different significantly. But for a group of students who took full e-learning ways was not better than other (blended-learning and conventional) in spite of full e-learning and other conventional was not different significantly.

2. There was no significant attitude difference to e-learning between blended learning students to full e-learning.

The students attitude to mathematics e-learning was positive

3. Correlations of pre-learning knowledge. HOTS. Students attitude to e-learning. and login duration

a. There was significant correlation between HOTS to pre-learning knowledge. But there was no correlation between HOTS and students attitude to e-learning. It was different to university B which there was significant correlation between students attitude to mathematics e-learning and its HOTS.

b. There was significant correlation between students attitude to mathematics e-learning and duration of login. But there was no correlation between HOTS and duration of login.

The implications from this study are:

1. The option of mathematics learning model was the beginning effort key to develop the power of the student's mathematics.

2. At this time the role of the lecturer could not be fully replaced by technology.

3. It is required to analyze the lack of this learning model or explore the other alternative learning model to increase the mathematical power. Especially that develop deductive reasoning.

4. The learning program that has the character of technology. has the potency to become the study choice in the future.

5. The importance of the balance of the learning component is to create the learning effectiveness.

6. The importance of the socialization of the study culture is based on technology basis.

\section{References}

Chaeruman, U. A. (2004). Integrasi Teknologi Telekomunikasi dan Informasi (TTI) ke dalam Pembelajaran. Makalah Seminar Nasional Teknologi Pembelajaran. Jakarta: Universitas Terbuka

Cute, A., Thompson, M., and Hancock, B. (1999). Handbook of Distance Learning. The McGraw-Hill.

Kamarga, H. (2002). Belajar Sejarah melalui E-learning. Jakarta: Intimedia.

Linde, E. (2004). Online Teaching and Learning. Makalah Seminar pada tanggal 16 Pebruari 2004 di Unpad Bandung.

Mueller, D. (1986). Measuring Social Attitudes, A Handbook for Researches and Practitioners. New York and London: Teachers College, Columbia University.

National Council of Teacher of Mathematics (NCTM). (2000). Principles and standards for School Mathematics. Reston. VA: NCTM.

Siahaan, S. (2003). “E-Learning (Pembelajaran Elektronik) sebagai Salah Satu Alternatif Kegiatan Pembelajaran”. Jurnal Pendidikan dan Kebudayaan. No. 042. Tahun Ke-9. Mei 2003.

Simonson, M., et al. (1999). Theory and Distance Education: A New Discussion. [Online]. Tersedia: http://www.uni-oldenburg.de/zef/cde/found/simons99.htm [23 juni2004] 
Soekartawi. (2003). E-learning di Indonesia dan Prospeknya di Masa Mendatang. Makalah disampaikan pada Seminar Nasional E-learning Perlu E-Library’ di Universitas Kristen Petra Surabaya. [Online]. Tersedia: Http://Incuvl.petra.ac.id/indonesia/bimbing/elearning2.pdf.

Soekartawi, (2004). "Beberapa Kesulitan dalam Pelaksanaan Pembelajaran Berbasis Web pada Sistem Pendidikan Jarak Jauh”. Teknologi Pembelajaran. Jakarta: PUSTEKKOM.

Thompson. at al. (2000). Perspective in Quality online Education. [Online]. Tersedia: http://www.sloan-c.org/publications/view/v2n7/pdf

Triandis, H. C. (1971). Attitude and Attitude Change. Foundations of Social Psychology Series. New York. London. Sydney. and Toronto: John Wiley \& Sons. Inc.

Wildavsky, B. (2001). Want More from High School? Special Report: E-learning. [Online]. Tersedia: http:/www.usnews/edu/elearning/articles. 
